\title{
Assessing the Relationships between Private Investment, Employment and Output in the Manufacturing Sector in Malaysia
}

\author{
Noor Al-Huda Abdul Karim* and Khoo Yin Yin \\ Universiti Pendidikan Sultan Idris, Malaysia \\ *Corresponding author: nooralhuda@fpe.upsi.edu.my
}

Received: July 17, 2014 Accepted: October 25, 2014 Published: February 1, 2015

doi:10.5296/jmr.v7i2.6943 URL: http://dx.doi.org/10.5296/jmr.v7i2.6943

\begin{abstract}
The purpose of this study was to evaluate the influences of private investment inflows on employment and output across manufacturing industries. The study covered a time period from 1980 to 2010 for the variable of private investment inflows and from 1981 to 2011 for the variables of employment and output. There were seven cross-section units to represent seven categories of industries for the analysis. Using a regression technique, the estimated coefficients private investment flows had statistically significant influences on the levels of employment and output. Using Pearson Correlation technique, there was a positive correlation between employment and output. Private investments are encouraged to accelerate output growth and employment enhancement in the sector.
\end{abstract}

Keywords: Private investment, Employment, Output 


\section{Introduction}

In the mid-1980s, significant development of manufacturing sector in Malaysia began after the country changed its focus from agricultural sector. Various incentives and liberal policies had been provided in order to promote foreign and domestic investment flows into the sector such as enactments of Investment Incentives Act and Free Trade Act, liberal policies on equity and tax incentives (MIDA, 2001). In 1986, the First Industrial Master Plan (IMP) 1986-1995 was implemented to achieve output performance targets of selected priority industries. These industries were considered important to increase output for exports. To achieve the targets, foreign investments were strongly promoted due to insufficient domestic investments in the industries. Later, the Second IMP 1996 - 2005, as opposed to the First IMP 1986-1995, a cluster development approach was used to move up the value-added chain in Malaysia's industrial development (MITI, 1996). In the Third IMP 2006-2020, an emphasis is given to the quality aspect of private investment. Private companies are expected to enhance their capacities and capabilities towards achieving higher competitiveness in both domestic and international markets (MITI, 2006).

In May 2009, the National Economic Advisory Council (NEAC) formulated a New Economic Model (NEM), which is aimed at transforming Malaysia into a high income economy by 2020 (NEAC, 2011). The NEM has three goals to achieve: high income (Targets US\$15,000 - 20,000 per capita by 2020), sustainability (Meets present needs without compromising future generations) and inclusiveness (Enables all communities to fully benefit from the wealth of the country). The NEM goals are in line with the goals set forth in Vision 2020, which envisions the country as a fully developed country economically, socially, politically and spiritually by the year 2020. To move the country forward, there are four pillars to drive change: 1Malaysia (People First, Performance Now), Government Transformation Programme (6 National Key Result Areas (NKRAs)), Economic Transformation Programme (8 Strategic Reform Initiatives (SRIs)) and the Tenth Malaysia Plan 2011-2015 (Macroeconomic growth targets and expenditure allocation). Transformation Programme (8 Strategic Reform Initiatives (SRIs)) and the Tenth Malaysia Plan 2011-2015 (Macroeconomic growth targets and expenditure allocation).

In the NEM, the private sector will be the main driver of market growth. The private sector has to create a heightened profile in the transformation programme. In industrial activities, workers must be matched efficiently to increase productivity so that wages can be raised. This is relevant to an establishment of quality education system, which nurtures skilled, inquisitive and innovative workers to improve productivity in manufacturing industries. In the aspect of output, manufacturing accounted for more than 30 per cent by 2000s from less than 15 per cent in 1970 (NEAC, 2010). The sector was primarily focused on the electrical and electronics (E\&E) industry, which spawned the growth of other industries in supply, logistics and services. Until now, Malaysia is a major exporter of consumer and industrial electronic products.

\subsection{Problem Statement and Objectives}

The manufacturing sector was dynamic in terms of employment and output growth during the 
period of First Outline Perspective Plan or OPP1 (1971-1990). The average annual employment growth was 6.4 per cent and output growth was 10.5 per cent from 1970-1979. During the period of OPP2 (1991-2000), there was a significant decline in the average annual employment growth, 2.1 per cent and output growth was 10.1 per cent from 1995 to 2000. It was caused by the structural changes in employment (Malaysia, 2001). Increasing capital intensity and the use of technology led to an increase in demand for highly skilled and educated workers by the private companies. During the period of OPP3 (2001-2010), the average annual employment growth was declined by 1.4 per cent and output growth was 6.5 per cent. For the period, main emphasis was given on employees with tertiary education in science and technical fields to meet the growing requirements of the sector (Malaysia, 2001). In 2012, MIDA reported 182,841 jobs that had been created in the sector (MIDA, 2012). Nonetheless, productivity has not grown fast enough to strengthen economic growth of the country due to lack of creativity and innovations. In employment aspect, skilled labour has declined across industries and employers have to rely on unskilled foreign workers. Malaysia thus needs a radical change in its approach that can be a catalyst to unleash growth potential.

From the problem statement, the relationship between private investment, employment and output are opened to question of existence. Analyses are needed to find out the influences of private investment on levels of employment and output. In exploring detailed information about scenario of private investment, employment and output in the manufacturing sector, the three research questions to be addressed are: Does private investment significantly influence the level of employment in the manufacturing sector? Does private investment significantly influence the level of output in the manufacturing sector? Is there a significant relationship between employment and output in the manufacturing sector? The general objective of this study is to assess the relationship between private investment, employment and output in Malaysia's manufacturing sector. The specific objectives are: 1. To evaluate the influence of private investment on employment in the sector, 2. To evaluate the influence of private investment on manufacturing output and, 3. To examine the relationship between employment and output in the sector.

\section{Literature Review}

Private sector is a major driver of growth in employment and output. In McAleese and Counahan (1979), foreign investment activities in the private sector provide employment opportunities to local people in the host countries. Moreover, their role in human resource management is important for employment stability (Dunning, 1993). In the work of Pfeffermann (2001), private companies play their role in sustainable job creation. Employment generates income for people and improves their standard of living and quality of life. Other studies focused on the size of wage effects of private investment (Aitken, Harrison and Lipsey, 1996; Teal, 2000; Naylor and Santoni, 2003). The workers who are given salaries and wages are capable to increase their purchasing power in goods market. Increase in demand for goods stimulates production of output in economy.

At an aggregate level, private investment (foreign and local invesments) contributes to economic growth of developing countries (Khan and Reinhart, 1990; Serven and Solimano, 
1990; Coutinho and Gallo, 1991; Romer, 1993; Khan and Kumar, 1997). In the empirical results on the relative effects of public and private investment on growth, private investment has a larger positive impact on growth than public investment. Khan and Kumar (1997) took a large sample of 95 developing countries over the period 1970-90 and did a variety of empirical tests. In their results, the large impact of private investment on growth was especially during the 1980s. Even the rates of return of private investment increased over time. There were significant regional variations of the levels of public and private investment on growth and in the associated rates of return. The difference was most apparent for Latin America and Asia, but much less pronounced for Africa, Europe and the Middle East country groupings. Berthélemy and Démurger (2000) examined the relationship between foreign direct investment and economic growth from 1985 to 1996. In their study, a model of endogenous growth highlights the technology transfer from foreign companies that causes economic growth. Economic growth also conversely influences the inflows of foreign capital. Workers' capability to use the transferred technology is of importance.

In the empirical work of Jalilian and Weiss (2002), foreign investment inflows in the Association of Southeast Asian Nations (ASEAN) region were found associated with higher economic growth. Foreign investment is complements local investment to increase aggregate level of output that can contribute to significant economic growth in Malaysia. Bayraktar (2003) took private investment as a proxy for private sector development in the member countries of the Organisation of Islamic Cooperation (OIC). The countries are required to achieve certain levels of investment if they aim high for economic growth. Private investment is crucial in the development agenda because it provides various income and job opportunities. Since investment is associated with long run benefits, the main strategies of private sector development need an implementation period. In the study of Falki (2009), there was an impact of foreign direct investment on economic growth of Pakistan for the period 1980 to 2006. The relationship between foreign direct investment and economic growth was analysed by using the production function based on the endogenous growth theory. Other variables such as trade, domestic capital and labour were also used in the analysis.

Ochai and Mukasa (2012) used panel data analysis to investigate the effects of investment climate factors on manufacturing firms' growth in Uganda. There are low levels of manufacturing sector share in Gross Domestic Product (GDP) in most African countries. The results show that firm size, firm age, and average education are the main determinants of firm growth in a sample of Ugandan manufacturing firms. These results have important policy prescriptions to increase firm growth of output. In Aurangzeb and Ul Haq (2012), the impact of investment activities on Pakistan's economic growth was examined by using a yearly data for the period of 1981-2010. A multiple regression technique was used to analyse the relationship between dependent variable (GDP) and independent variables (public investment, private investment and foreign direct investment). In their results, all independent variables have significant and positive impact on the country's economic growth. The granger causality test found bi directional relationship of GDP with foreign direct investment and public investment while unidirectional relationship of GDP was found with private investment.

The empirical study of Habib and Sarwar (2013) focuses on the impact of foreign direct 
investment on employment level in Pakistan. Using time series data from data 1970-2011, the variables selected were employment level, foreign direct investment, exchange rate and GDP per capita. By using a Co-integration approach, their analysis result shows the relationship between the dependent and independent variables. The positive relationship between foreign direct investment and employment level suggests that the inflow of foreign direct investment brings more employment opportunities to the country. An increase in GDP per capita also causes higher employment level, which increases the society's welfare.

From the above literature, private investment activities are seen important to increase employment and output in a country. Income received by people who are employed in the private sector is used in their daily consumption, which in turn becomes profits for the companies. These intensify the companies to increase their production of output, which will contribute to national economic growth.

\section{Methods to Analyse}

Based on the past literature, an illustration of the importance of private investment in increasing employment opportunities and manufacturing output in Malaysia is developed as follows:

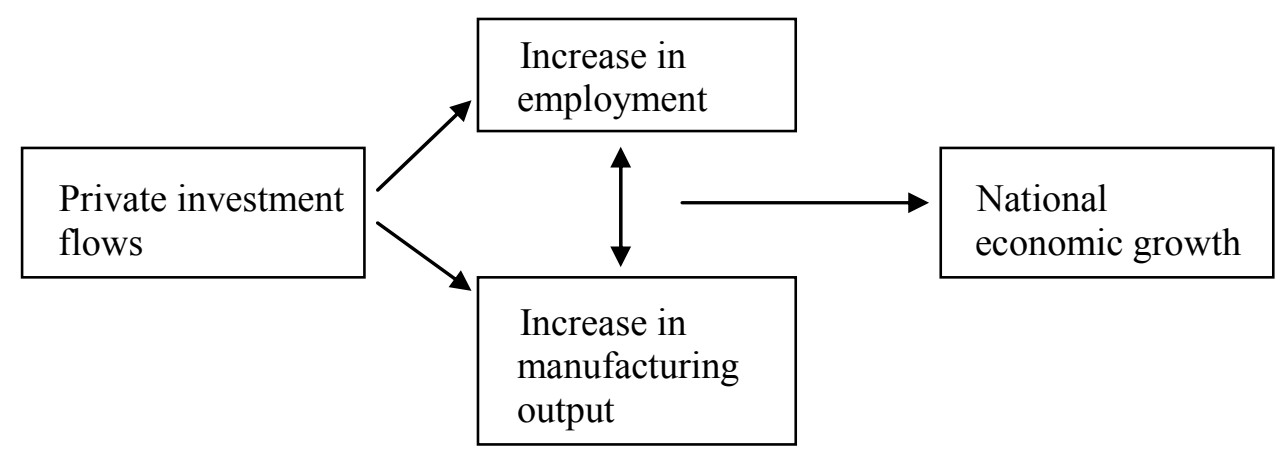

Figure 1. Model for the Relationship between Private Investment, Employment and Output in Malaysia's Manufacturing Sector

The analysis is based on manufacturing industries in which there were private investment inflows in their approved projects. A set of panel data of private investment for the industries is from 1980 to 2010. As for the variables of employment and output, their time period is from 1981 to 2011. All data on private investment and employment were taken from the office of Malaysian Industrial Development Authority (MIDA). Data on manufacturing output were taken particularly from Bank Negara Malaysia/Central Bank of Malaysia (BNM). They were some taken from Malaysia International Trade and Industry (MITI) and Department of Statistics.

For the purpose of analysis, the manufacturing industries were categorised into seven groups: 1. Food manufacturing, beverages and tobacco; 2 . Textiles, textile products, leather, leather products and footwear; 3. Wood, wood products, furniture, fixtures, paper, printing and publishing; 4. Chemical, chemical products, petroleum products, rubber products and plastic products; 5. Non-metallic mineral products, basic metal products and fabricated metal 
products; 6. Electronics and electrical products; 7. Machinery manufacturing, transport equipment, Scientific and measuring equipment and other manufactures.

Data on private investment (PI) and manufacturing output (MO) were deflated by GDP deflator in order to obtain their real values in the base year prices $2005=100$ :

$$
\begin{aligned}
& \text { Real value of PI inflows }=(\text { nominal PI inflows/GDP deflator }) \times 100 \\
& \text { Real value of } \mathrm{MO}=(\text { nominal MO/GDP deflator }) \times 100
\end{aligned}
$$

The economic model of employment (EMP) in relation to private investment is

$$
\mathrm{EMP}=\mathrm{f}(\mathrm{PI})
$$

and the economic model of manufacturing output (MO) is

$$
\mathrm{MO}=\mathrm{f}(\mathrm{PI})
$$

where

EMP is the annual total potential employment in approved manufacturing projects in Malaysia by industry;

MO is the annual real value of output in Malaysia's manufacturing sector by industry;

PI is the annual inflow of real private investment in approved manufacturing projects in Malaysia by industry (in ringgit);

Theoretically, the variable of PI is expected to have positive relationships with the variables of EMP and OP. Increase in private investment would increase job opportunities and the level of output in the manufacturing sector.

The econometric models are as follows:

$$
\begin{aligned}
& \operatorname{InEMP}_{\text {it }}=\beta_{0}+\beta_{1} \operatorname{InPI}_{\text {it }-1}+\mathrm{u}_{\mathrm{it}} \\
& \mathrm{InMO}_{\text {it }}=\beta_{0}+\beta_{1} \mathrm{InPI}_{\text {it }-1}+\mathrm{u}_{\mathrm{it}} \\
& \quad \mathrm{i}=1, \ldots \ldots \ldots . \text { ith industry, } \mathrm{t}=1981, \ldots \ldots \ldots . .2011
\end{aligned}
$$

where $\beta_{0}$ is the intercept and $\beta_{1}$ is the slope coefficient or parameter that measures the elasticities of EMP and MO with respect to the explanatory variable, PI at the cross-sectional unit $i$ and time period t. In denotes the natural logarithm. The stochastic disturbance term, $\mathrm{u}$, is assumed to be independently and normally distributed with zero mean and constant variance.

The lagged one period of PI is to reflect that there is usually a lag between the point at which a company's investment fund is available and the point at which its production and operations begin. The proposed econometric models are in a log-linear form to produce better results of expected sign of the explanatory variable than the linear models. Moreover, the log-linear models may reduce the severity of heteroscedasticity.

This study also examines the availability of relationship between employment and 
manufacturing output by using Pearson Correlation technique.

For the two models, we had attempted to obtain data on actual private investment instead of approved private investment inflows into the manufacturing sector but they were not available. In the approved private investment, there were cash flows from both foreign and local firms although not fully actualised. More than 90 percent of their approved projects were implemented. Therefore the data on approved private investment inflows are considered reliable for estimating the model.

In our analysis, a pooled econometric estimation was done to allow for cross-sectional heteroscedasticity and time-wise autoregressive behaviour in the error term (Greene , 2008, Chapter 9). The estimation of coefficients in the model was obtained by using generalised least squares (GLS) procedure. The GLS estimator is developed by transforming a model with heteroscedastic disturbances into one with homoscedastic disturbances. Then the ordinary least squares (OLS) technique is applied to the transformed model. The GLS estimator is considered the best linear unbiased estimator for coefficient $\beta$ in an econometric model. The whole population is included in the analysis. Therefore the regression coefficients in the two models can be estimated to explain the levels of employment and manufacturing output, respectively in general.

\section{Estimation Results}

Using a regression technique, the estimation results of elasticities were obtained. As shown in the two tables, the estimated coefficients, the inflows of private investment are statistically significant to explain the level of employment and real manufacturing output, respectively.

Table 1. Estimates of private investment elasticities of employment, 1981 2011

\begin{tabular}{|l|l|l|l|l|}
\hline \multicolumn{1}{|c|}{ Variable } & Estimated coefficient & \multicolumn{1}{|c|}{ Standard error } & t-ratio & p-value \\
\hline $\begin{array}{l}\text { Private Investment } \\
\text { Inflows (PI) }\end{array}$ & $0.28147^{*}$ & 0.0203 & 13.85 & 0.000 \\
\hline Constant & & & & \\
\hline
\end{tabular}

Note: $\quad$ Buse $(1973)$ R-square $=0.4692 . F($ from mean $)=191.828(p$-value $=0.000)$.

Number of observations $=217 . *$ Significant at the 1 per cent level.

The $\mathrm{p}$-value is appropriate for one-sided hypothesis test.

In the Table 1, the private investment variable has a positive relation with employment. The coefficient on the private investment variable is statistically significant at the one per cent level with an elasticity of 0.28 . It indicates that higher level of private investment flows into the sector lead to an increase in employment opportunities in the sector. The manufacturing industries are motivated by profit maximisation to increase their output for the needs of local consumption and particularly for world export markets. As for foreign companies, this condition influences them to increase their investments to their subsidiaries in Malaysia. Hence, labour demand increases because the companies expect a lower cost of production at the expense of various facilities provided in industrial estates in the country. Moreover, increasing labour productivity reduces labour cost in their industries. 
Table 2. Estimates of private investment elasticities of output, 1981 2011

\begin{tabular}{|l|l|l|l|l|}
\hline \multicolumn{1}{|c|}{ Variable } & \multicolumn{1}{|c|}{ Estimated coefficient } & \multicolumn{1}{|c|}{ Standard error } & t-ratio & p-value \\
\hline $\begin{array}{l}\text { Private Investment } \\
\text { Inflows (PI) }\end{array}$ & $0.44075^{*}$ & 0.0201 & 21.96 & 0.000 \\
\hline Constant & 0.71799 & 0.4268 & 1.682 & 0.093 \\
\hline
\end{tabular}

Note: Buse $(1973) \mathrm{R}$-square $=0.6897 . \mathrm{F}($ from mean $)=482.293(\mathrm{p}$-value $=0.000)$.

Number of observations $=217 .{ }^{*}$ Significant at the 1 per cent level.

The p-value is appropriate for one-sided hypothesis test.

The positive sign of the private investment variable implies that the level of output increases when Malaysia largely promotes various types of investment in the manufacturing sector. The variable's estimated coefficient is statistically significant at the one percent level with 0.44 , suggesting that private companies' production size of output in the country is sensitive to the inflows of private investment.

Referring to the Table 1, the R-square value of the employment model, 0.47 indicates that the private investment variable can jointly explain the variation in the level of employment about 47 percent, while the remaining 53 percent of the variation is explained by other possible variables that are not selected in the model. As for the Table 2, the R-square value of the output model, 0.69 indicates that the private investment variable can jointly explain the variation in the level of output about 69 percent, while the remaining 31 percent of the variation is explained by other possible variables outside the model. The levels of percentage are reasonable for the models that have only one explanatory variable, respectively. In the overall test of 5 percent level of significance, the calculated p-value of the F-statistic is close to zero for each table. It suggests that both models are significant.

In the other results, there is a positive relationship between the level of employment and the level of output produced in the sector. The Pearson Correlation technique shows that there is a statistically significant correlation at $0.38(\mathrm{p}$-value $=0.000)$ between the two variables. This correlation is important to contribute to the achievement of economic growth in Malaysia.

In the Economic Transformation Programme of the designed New Economic Model (NEM), Malaysia needs to achieve total investments of RM1.4 trillion during the period 2011-2020, with 92 per cent (RM1.3 trillion) coming from the private sector and the balance of 8 per cent (RM108 billion) from the public sector. In the shorter term, the Tenth Malaysia Plan, 2011 -2015 targets private investment to grow at 10.9 per cent per annum, or RM148 billion worth of private investments per year. In 2012, realised private investments (measured in terms of Gross Fixed Capital Formation - GFCF) was RM139.5 billion as compared to RM111.8 billion in 2011. Therefore Malaysia had exceeded the private investments target of RM127.9 billion for 2012 by 9.1 per cent. The Economic Transformation Programme provides platforms in the form of wide-ranging investments through its entry-point projects (EPPs) and business opportunities across the economy. It enables the manufacturing and service sectors to accelerate their output growths. 


\section{Conclusions, Implications and Significance}

The activities of local and foreign companies in Malaysia are guided by the government policies so that they can give greater contribution to employment opportunities and output growth in the country. Malaysia takes a balanced approach in economic management to meet national objectives of economic and social stability.

The analysis covers employment and output data in relation to private investment from the year 1981 to 2011 for seven categories of manufacturing industries. The categorisation into seven major groups was done because there was lack of data of a detailed breakdown for each type of manufacturing output. In the two log-linear models of employment and output, the estimated coefficients of private investment flows have statistically significant influences on the levels of employment and output in the manufacturing sector. Large flows of private investment will bring more employment opportunities in the sector. The level of output will increase too. Motivated by profit maximisation, the private companies increase investments that will create more jobs so that their production of output can be increased in their industries in Malaysia. Goods produced are to meet local and foreign markets. High labour productivity further minimizes their costs of production. Moreover, the positive correlation between employment and output in the sector is important for the contribution share of economic growth in the country.

In the present New Economic Model (NEM), private sector needs stability and certainty in the policy actions so that corporate decisions on long-term investment and growth strategies can be made by the government with confidence. To promote a long-term stable investment climate, the establishment of policies should be positive on both growth and distribution. Providing good infrastructure and logistics in industrial areas enables to attract multinational export activities in Malaysia. In the effort, the Malaysian Investment Development Authority (MIDA) plays an effective role in dealing with investment promotion.

To maintain competitiveness of Malaysia's manufacturing sector, the policy actions should strengthen the sector itself and accelerate the country's shift towards high value-added, high technology, knowledge intensive and innovation-based industries. Private investments are encouraged to accelerate output growth and employment enhancement. In short, there is a need to increase in total private investment rapidly so that the sector can be strengthened in effort to face changes in the global economic environment. Job creations and industrial output from expanded and newly existing industries are expected to increase in the sector.

\section{Acknowledgement}

This study was supported by a small research grant 2012 from the Universiti Pendidikan Sultan Idris, Malaysia.

\section{References}

Aitken, B., Harrison, A., \& Lipsey, R. E. (1996). Wages and Ownership: A Comparative Study of Mexico, Venezuela, and the United States. Journal of International Economics, 40(3/4), 345-371. http://dx.doi.org/10.1016/0022-1996(95)01410-1 
Athukorala, P.C. (1998). Swimming Against the Tide. ASEAN Economic Bulletin, 15(3), 281-289. http://dx.doi.org/10.1355/AE15-3C

Aurangzeb \& Ul Haq, A. (2012). Impact of Investment Activities on Economic Growth of Pakistan. Business and Management Review, 2(1), 92-100.

Bayraktar, B. (2003). The Role of Private Sector Investments in the Economic Performance of OIC Member Countries. Journal of Economic Cooperation, 24(1), 63-110.

Berthélemy, J. C., \& Démurger, S. (2000), Foreign Direct Investment and Economic Growth. Review of Development Economics, 4(2), 140-155. http://dx.doi.org/10.1111/1467-9361.00083

BNM (Bank Negara Malaysia). (various issues). Monthly Statistical Bulletin. BNM: Kuala Lumpur.

Coutinho, R., \& Gallo, G. (1991). Do Public and Private Investment Stand in Each Other's Way, 1991 WDR Background Paper, October, World Bank.

Dunning, J.H. (1993). Multinational Enterprises and the Global Economy. Addison Wesley: Wokingham.

Falki, N. (2009). Impact of Foreign Direct Investment on Economic Growth in Pakistan. International Review of Business Research Papers, 5(5), 110-120.

Greene, W.H. (2008). Econometric Analysis (6 ed.). Prentice Hall: Upper Saddle River NJ.

Habib, M. D., \& Sarwar, S. (2013). Impact of Foreign Direct Investment on Employment Level in Pakistan: A Time Series Analysis. Journal of Law, Policy and Globalization, 10, 46-56.

Jalilian, H., \& Weiss, J. (2002). Foreign Direct Investment and Poverty in the ASEAN Region. ASEAN Economic Bulletin, 19(3), 231-253. http://dx.doi.org/10.1355/AE19-3A

Khan, M.S., \& Reinhart, M.C. (1990). Private Investment and Economic Growth in Developing Countries. World Development, 18(1), 19-27. http://dx.doi.org/10.1016/0305-750X(90)90100-C

Khan, M. S., \& Kumar, M.S. (1997). Public and Private Investment and the Growth Process in Developing Countries. Oxford Bulletin of Economics and Statistics, 59(1), 69-88. http://dx.doi.org/10.1111/1468-0084.00050

Malaysia, Government. (1971). The First Outline Perspective Plan 1971-1990. Government Press: Kuala Lumpur.

Malaysia, Government. (1991). The Second Outline Perspective Plan 1991-2000. Government Press: Kuala Lumpur.

Malaysia, Government. (2001). The Third Outline Perspective Plan 2001-2010. Government Press: Putrajaya.

McAleese, D., \& Counahan, M. (1979). Multinational Corporations during the Recession. Oxford Bulletin of Economics, 41(4), 345-358. http://dx.doi.org/10.1111/j.1468-0084.1979.mp41004007.x

MIDA (Malaysian Industrial Development Authority). (1996). Annual Report 96. MIDA: 
Kuala Lumpur.

MIDA. (2001). Malaysia: Investment in the Manufacturing Sector - Policies, Incentives and Facilities. MIDA: Kuala Lumpur.

MIDA (Malaysian Investment Development Authority). (2012). Malaysia Investment Performance 2012 - Investment for Transformation. MIDA: Kuala Lumpur.

MITI (Ministry of International Trade and Industry Malaysia). (1996), Malaysia International Trade and Industry Report. Government Press: Kuala Lumpur.

MITI. (2006). Malaysia International Trade and Industry Report. Government Press: Kuala Lumpur.

Naylor, R.A., \& Santoni, M. (2003), Foreign Direct Investment and Wage Bargaining. Journal of International Trade and Economic Development, 12, 1-18. http://dx.doi.org/10.1080/0963819032000049178

NEAC (National Economic Advisory Council). (2010). New Economic Model for Malaysia. Government Press: Kuala Lumpur.

NEAC. (2011), Welcome to NEAC. http://www.neac.gov.my, accessed on 3 July 2013.

Ochai, N. A. M., \& Mukasa, I. (2012). The Effects of Investment Climate on Manufacturing Firms' Growth in Uganda. Investment Climate and Business Environment Research Fund, ICBE-RF Research Report No. 19/12.

Pfeffermann, G. (2001). Poverty Reduction in Developing Countries: The Role of Private Enterprise. Finance and Development, 38(2), June, 42-45.

Romer, P. (1993). Idea Faps and Object Gaps in Economic Development. Journal of Monetary Economics, 32, 543-573. http://dx.doi.org/10.1016/0304-3932(93)90029-F

Serven, L., \& Solimano, A. (1990). Private Investment and Macroeconomic Adjustment: Theory, Country Experience, and Policy Implications, Macroeconomic Adjustment and Growth Division. Unpublished: World Bank.

Teal, F. (2000). Private Sector Wages and Poverty in Ghana: 1988-1998. Working Paper Series, WPS/2000-6, April, Centre for the Studies of African Economies (CSAE): Oxford University.

\section{Copyright Disclaimer}

Copyright for this article is retained by the author(s), with first publication rights granted to the journal.

This is an open-access article distributed under the terms and conditions of the Creative Commons Attribution license (http://creativecommons.org/licenses/by/3.0/). 